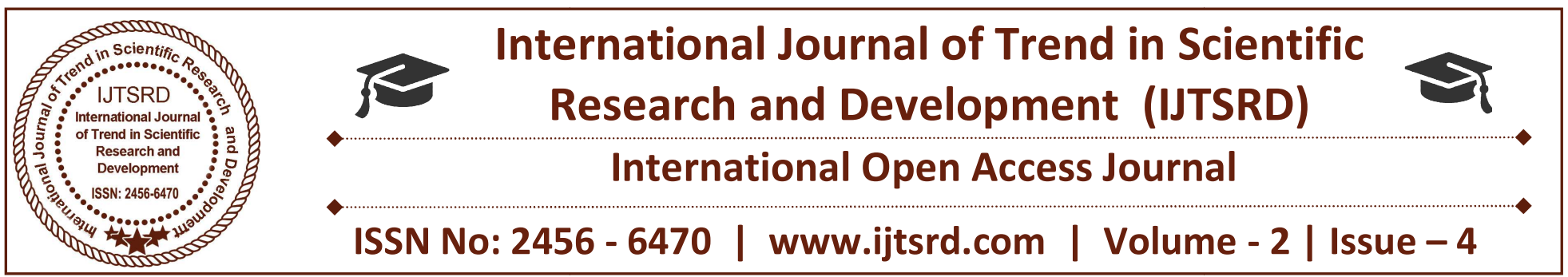

\title{
Measuring the Influence of Internal Service Quality on Health Care Delivery
}

\author{
(A case of selected Private Hospitals in Visakhapatnam)
}

\author{
Dr. A. V. Nageswara Rao \\ Professor, Sharda University, \\ Greater Noida, Uttar Pradesh, India
}

\begin{abstract}
The objective of this study is to examine the influence of Internal Service Quality at various levels in Organization on Health care Delivery. The research method used in the study is Descriptive and Correlation is used to test the relationship among the variables. The target respondents Population who participated in the study are $(\mathrm{N}=200)$ who are the Medical Duty staff in private hospitals around Visakhapatnam, Andhra Pradesh, India. A structured Questionnaire of Di Xie(2005) Internal Service Quality was used to investigate its influence on Health care Delivery. The research findings showed that there is significant positive correlation ( $\mathrm{r}=0.554$, $\mathrm{p}<0.001$ ) between Internal service quality at various levels in organization on Health care delivery. The Results of Cronbach Alpha measurement showed that the score of reliability is above 0.70 which indicates an acceptable level The research findings adds to the literature the importance and positive influence of Internal service quality on Health care Delivery.
\end{abstract}

Keywords: Internal service Quality, Health care Delivery, Quality services, Organization

\section{INTRODUCTION}

Internal Service Quality is gaining prominence in the present Global competitive environment.

The theoretical concept of Internal Service Quality(ISQ) was first introduced by (Sasser ,1976) who considered the employees as internal customers. They contend that providing the external customers with quality services requires the provision of satisfaction and quality services to internal customers (Liang wang, 2010). Internal service quality refers to what employees feel about the quality of services they render to the Customers. (Hallowell, et al, 1996).Delivering Quality service is very important and even considered essential for survival and sustainability. (Parasuraman et al., 1985; Reichheld and Sasser, 1990; Zeithaml et al., 1990).Post Globalization in India, the number of private players in Health care sector have increased and they are under immense pressure to deliver Quality services . The public sector organizations have come under increasing pressure to deliver quality services (Randall and Senior, 1994) and improve efficiencies (Robinson, 2003). Customer needs, expectations and preferences are continuously changing in the context of health care services and their quality requirements. The Price for the Health care services do vary and depend upon the type of Quality service. The Service Quality practices in public sector organizations are slow and is further dependent on various procedures and practices within the organization. (Teicher et al., 2002). Based on the study of Heskett (1994) Internal service quality acts as a link to connect employee satisfaction, loyalty to customer satisfaction. The present study may offer the opportunity to both HR management and employees to build an understanding of internal service quality. The results would be used to offer suggestions for improvements in internal service quality for Organizations involved in Health care Delivery. 


\section{LITERATURE REVIEW}

(Parasuraman, et al, 1988) defines service quality as an overall judgement similar to attitude towards the service and generally accepted as an antecedent of overall customer satisfaction (Zeithaml and Bitner, 1996) defined service quality as the ability of the organization to meet or exceed customer expectations in the process of delivering Quality service. It is also a tool to measure the difference between customer expectations of service and perceived service (Zeithaml et al., 1990).

Internal service quality pertaining to the components of health care delivery system designed within the framework of a Likert's seven point scale (Chahal Hardeep, 2003; Bhat, Ramesh, 1999; Sharma and Chalal, 1995; Youseef and Bovaird 1995; and Lein and Tang, 2000)

Perceived service quality results from comparisons by customers of expectations with their perceptions of service delivered by the suppliers (Zeithaml et al., 1990).If expectations are greater than performance, then perceived quality is less than satisfactory and hence customer dissatisfaction occurs (Parasuraman et al., 1985; Lewis and Mitchell, 1990)Services unlike tangible products are produced and consumed at the same time in the presence of the customer and the service producer. The presence of the human element during the service delivery process greatly increases the probability of error on the part of employees and customers. This error is due to intangible behavioral processes that cannot be easily monitored or controlled (Bowen, 1986). However, although a substantial amount of service quality research has focused on service customers' perceived service quality (Parasuraman et al., 1988; Carman, 1990; Parasuraman et al., 1991; Babakus and Boller, 1992; Cronin and Taylor, 1992; Babakus and Mangold, 1992), relatively little attention has been paid to exploring the factors that impact on service employees' behavior with regard to delivering service quality.

Service Quality has always attracted the attention of managers and leaders in organizations (Mackay \& Crompton, 1990).In the present Global competitive environment Organization seek to improve their performance through Innovation and Quality of Services they offer to Customers. As many researchers contend, organizations need to deal with both internal and external customers (Hauser et al.,
1996).Successful organizations need to emphasize the quality of services offered to both internal and external customers. Such organizations are astute enough to predict the changing needs of their customers, to concentrate on their organizational capability to offer high-quality services, and to see the quality of internal service as a tool to gain competitive advantage (Azzolini, 1993).(Zhen You, 2003) asserts that an important aspect of internal service quality is to see how employees of a division provide their colleagues with services. Thus, the quality of internal services affects employee satisfaction. (Meng Xia, 2003) contends that internal high-quality services increase employee satisfaction, which results in external customers' satisfaction and increased organizational performance. (Liang Wang ,2010) believes that attention to internal service quality is the starting point for employees', stakeholders', and external customers' satisfaction and eventually improved organizational performance. (Bellou and Andronikidis,2008) conducted a study on 16 big banks in Greece and reported that improved internal service quality in the banks affected the behavior and satisfaction of their external customers, which eventually improved banks' performance. (Sharma and Chahal, 1999) identified the need of evaluating the service quality of health care service pertaining to hospitals and the importance of Internal Service Quality at various levels in the organization.

\section{RESEARCH HYPOTHESIS AND MODEL}

A Research Hypothesis is formulated with the Independent variables of Internal Service Quality at various levels in Organization and testing its influence on Health Care Delivery taken as a Dependent Variable. A model is formulated to analyse the ultimate impact of the Internal Service Quality variables on the Dependent variable Health care delivery particularly in the context of Private hospitals. The Service quality procedures and practices are cost-effective and ranges from basic services to complex degree of services which includes state of the art equipment, facilities, skilled man power and Specialized medical staff well trained to handle the Customer complexities $24 * 7$, around the clock. A Research model is developed with the given Internal Service Quality variables and Dependent variable Health Care Delivery. 


\subsection{Hypothesis Formulation}

Ho1: Internal Service Quality has a significant positive influence on Health care Delivery
Ha1:Internal Service Quality do not have a significant positive influence on Health Care Delivery

\subsection{Research Model}

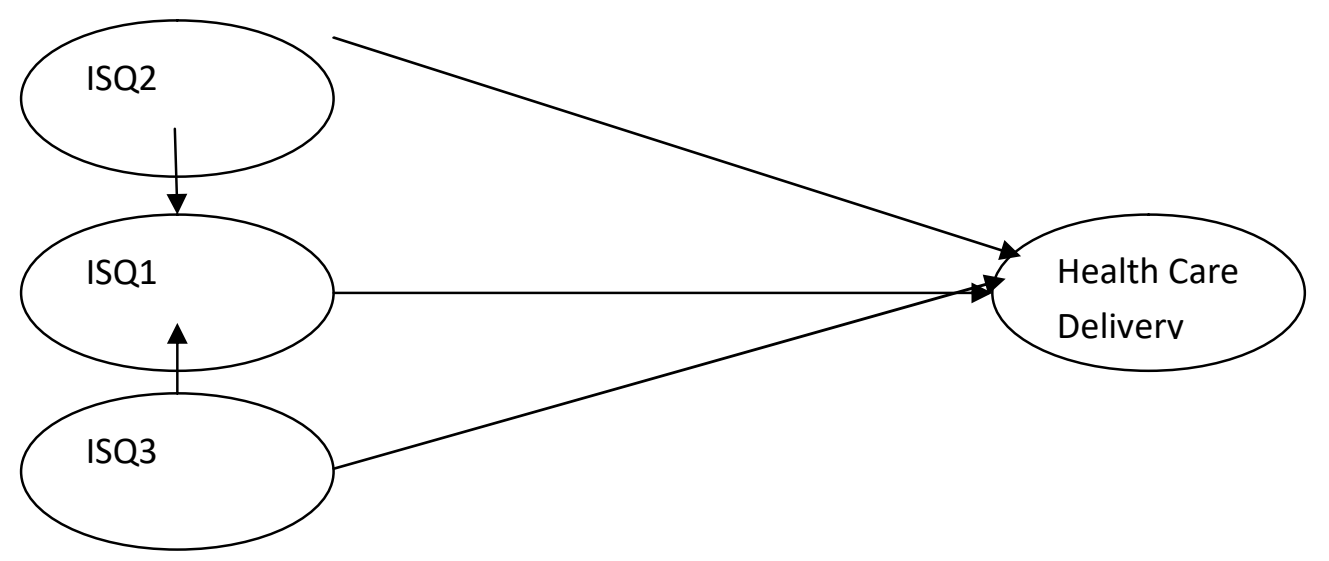

\section{RESEARCH METHODOLOGY}

\subsection{Methods and Procedure}

The Research method for the study is Descriptive in nature and Correlation is used to test the relationship among the variables. The population of the study is 220 and the target respondents are Duty staff in Private hospitals around Visakhapatnam, Andhra Pradesh, India. After verifying the collected data, the valid sample size for the present study is equal to $\mathrm{N}=200$. The data is collected through a Questionnaire developed by Di Xie (2005) with reference to Internal Service Quality (ISQ) . The independent variables for the study are taken as Internal Service Quality at various levels in Organization, Inter-Departmental level and Intra-Departmental level and the Dependent variable is taken as Home care Delivery. Each of the Independent variable consists of 10 items on a 7point Likert scale whereby the target respondents are explained the importance of Internal Service Quality data collection and its application to achieve the objectives. The Reliability analysis was also conducted using Cronbach Alpha, whereby the Reliability Co-efficient is $\alpha=0.70$ for Internal Service Quality questionnaire and $\alpha=0.76$ for Health care Delivery. The descriptive statistics which includes Frequency, Mean, Standard Deviation and various other tabulations are performed and Pearson Correlation is used to test the Hypothesis.

Table 1: Reliability Analysis, Mean \& S.D(N=200)

\begin{tabular}{|l|l|l|l|l|l|l|}
\hline S.No & Variables & Mean & S.D & 1 & 2 & 3 \\
\hline 1 & $\begin{array}{l}\text { Internal Service Quality at } \\
\text { Organization level }\end{array}$ & 0.82 & $(.88)$ & & \\
\hline 2 & $\begin{array}{l}\text { Internal Service Quality at Inter- } \\
\text { Departmental level }\end{array}$ & 4.2 & 0.72 & 0.42 & $(.85)$ & \\
\hline 3 & $\begin{array}{l}\text { Internal Service Quality at Intra- } \\
\text { Departmental level }\end{array}$ & 4.4 & 0.75 & 0.62 & .37 & $(.75)$ \\
\hline 4 & Health Care Delivery & 4.5 & 0.74 & 0.52 & .45 & $(.72)$ \\
\hline
\end{tabular}

All Variables intercorrelated at $\mathrm{P}<.01$

7 point Likert Scales,Cronbach Alpha reported in parenthesis 
The above table shows the Mean and Standard Deviations for the Independent Variables Internal Service Quality (ISQ) at various levels. The Reliability values of the Variables articulate the

Scope and Fitness: Examining the values from the above table it is found that Internal Service Quality at various levels have significant positive Correlation with Home Care Delivery. Therefore the statistical evidence supports the Ho1 Hypothesis which states that Internal Service Quality at various levels positively influences the Health care Delivery in Private hospitals.

Table 2: Relationship between Internal Service Quality Levels and Health care Delivery

\begin{tabular}{|l|l|l|l|}
\hline Variables at & $\mathbf{N}$ & $\mathbf{R}$ & $\mathbf{P}$ \\
\hline $\begin{array}{l}\text { Internal Service } \\
\text { Quality level } \\
\text { Organization }\end{array}$ & 200 & 0.52 & 0.001 \\
\hline $\begin{array}{l}\text { Internal Service } \\
\text { Quality at Inter- } \\
\text { Departmental level }\end{array}$ & 200 & 0.54 & 0.001 \\
\hline $\begin{array}{l}\text { Internal Service } \\
\text { Quality at Intra- } \\
\text { Departmental level }\end{array}$ & 200 & 0.57 & 0.001 \\
\hline $\begin{array}{l}\text { Health Care } \\
\text { Delivery }\end{array}$ & 0.54 & 0.001 \\
\hline
\end{tabular}

\section{Analysis and Results}

The Average age of the respondents of the study are 38 years and $62 \%$ of them have M.B.B.S/B.S or

Table 3: Factor Analysis of the Variables higher qualifications. Around $70 \%$ of the target respondents have more than 4 years of experience at the work place. The Mean scores for Internal Service Quality at various levels are Organization level 3.8, Inter-Departmental level 4.2 and Intra-Departmental level 4.4 and Home care Delivery is 4.5. Pearson Correlation test was conducted to analyse the degree of relationship among the Variables.

As illustrated in the above table the results exhibited a positive significant relationship between Internal Service Quality at various levels in the Organization and its positive influence on Health Care Delivery. The positive influence of Internal Service Quality at Organization level on Health care Delivery $(\mathrm{r}=0.52, \mathrm{P}<0.001)$. This adds to the existing Literature that every Sector has its specific Internal Service Quality procedures and its implementation at the work place requires support and co-ordination of Staff at various levels in the organization. As per (Yue Xia, 2009) internal service quality and internal customer satisfaction contribute to external customer satisfaction, which eventually influences organizational growth and profitability. The positive influence of Internal Service Quality at InterDepartmental level on Health care Delivery $(\mathrm{r}=0.54$, $\mathrm{P}<0.001)$. Internal service offered to employees can influence the quality of service offered to external customers, which significantly affects organizational performance (Chelladuraie, 2003). The positive influence of Internal Service Quality at IntraDepartmental level on Helath care Delivery $(\mathrm{r}=0.57$, $\mathrm{P}<0.001$ ). As per (Qin Nan,2009) study in Taiwanese insurance companies a significant positive correlation between different levels of internal service quality, employee job satisfaction,organizational performance and Service Delivery are found.

\begin{tabular}{|l|l|l|l|}
\hline Variables & \multicolumn{3}{l|}{ Factor Weights } \\
\cline { 2 - 4 } & 1 & 2 & 3 \\
\hline Internal Service Quality at Organizational level & .812 & .256 & .091 \\
\hline Infrastructure, equipments and facilities & .842 & .128 & .272 \\
Availability of specialized Staff & .810 & .110 & .190 \\
Convenient Customer Visiting hours & .723 & .027 & .312 \\
Prompt Service to Customers & .732 & .180 & .380 \\
Support Staff behavior \& Service & .710 & .175 & .095 \\
Well designed \& Labelled & & & \\
\hline
\end{tabular}


International Journal of Trend in Scientific Research and Development (IJTSRD) ISSN: 2456-6470

\begin{tabular}{|l|l|l|l|}
\hline Internal Service Quality at Inter-Departmental level & .121 & .812 & .120 \\
\cline { 2 - 4 } $\begin{array}{l}\text { Staff Co-ordination \& Service Delivery } \\
\text { Operational performance \& Communication }\end{array}$ & .110 & .725 & .190 \\
$\begin{array}{l}\text { Cost-effective Service Delivery } \\
\text { Access to specified Medicines } \\
\text { Equipment/Facilities for Customer mobility }\end{array}$ & .120 & .710 & .010 \\
\cline { 2 - 4 } $\begin{array}{l}\text { Internal Service Quality at Intra-Departmental level } \\
\text { Communication within Staff }\end{array}$ & .250 & .720 & .092 \\
\hline $\begin{array}{l}\text { I.T facilities in the Department } \\
\text { Maintenance of Error-Free Records }\end{array}$ & .151 & .730 & .268 \\
\cline { 2 - 4 } Staff Behavior \& Courteousness & .345 & .040 & .812 \\
\cline { 2 - 4 } & .320 & .280 & .715 \\
\hline
\end{tabular}

Extraction method: Principal Component Analysis

Rotation method: Varimax and Kaiser Normalization

To test the underlying relationship among the Variables ,Exploratory factorial analysis (EFA) with varimax rotation is applied for all the items of variables. The above table exhibits the results of Exploratory Factor analysis (EFA) performed with all the given items loaded resulting in a tri-component structure. It is further observed that Variables accounted for $68 \%$ of common variance. The composite variables are formulated based on the results of Exploratory Factor Analysis. The factorial weights above 0.42 are considered for Analysis and Interpretation. (Hair, Anderson, Tatham and Black, 1998).

\section{DISCUSSION AND CONCLUSIONS}

In the previous years before Liberalization, Privatization and Globalization the Health care Sector is completely governed by the Government and henceforth the concept of Internal Service Quality is at its nascent stage. With the sudden shift from Public sector to Private sector the Health care sector has witnessed investments by Businessmen, Net worth Individuals and Private organizations. The Prices are ever changing and Cost-effective as per the range of Medical services which are offered and demanded by various Customers visiting the Private Hosptials. The present study has taken the Internal Service Quality Model as important component for Private hospitals to concentrate and offer the best of the services to Global Customers. The study is carried out at Visakhapatnam, a cosmopolitan city with patients coming from various states and countries for medical services. Post-Globalization there is sea change in the Health Care sector and various services rendered by Private hospitals are unique to achieve competitiveness. The role of Internal Service Quality is important for their survival and long term sustainability. Previously the Health care sector is under the Public Sector governance and Internal Service Quality is not considered important to achieve competitiveness. (Hallowel,1998) contend that organizations need to improve the quality of their internal service so that they may provide external customers with better quality services. There are wide range of health services rendered by Private hospitals and the cost parameters, various medical schemes,tie-ups and agreements between the Government and allied Agencies play a vital role in the Health care Delivery. Internal Service Quality at various levels in the Organization play a significant role in the modern day Health care Delivery system. The present study has come out with suitable observations and findings which will be very useful for Private Hospitals and Organizations involved in the Health care Delivery. The role of communication and co-ordination among the various InterDepartments is essential for the in-time Service and upkeep of the standards in the Health care delivery. The Customers who are the patients visit the Private Hospitals from various Regions and Countries expect the best of the Service Quality matching their Expectations. In this context, Quality plays a significant role in meeting their expectations. Therefore the Top Management., Directors and HR should formulate and implement state of the art Internal Quality policy to meet the expectations of the Global patients who have varied tastes and preferences 
International Journal of Trend in Scientific Research and Development (IJTSRD) ISSN: 2456-6470

\section{REFERENCES}

1. Ahmadi A 2007. Relationship between service quality and satisfaction measurements spectators in stadiums hosting the AFC Champions League. MS thesis in Physical Education, Isfahan University.

2. Azzolini M, Shillaber J 1993. Internal service quality : Winning from the inside out. Journal of Quality Progress. 26(11): 75-89.

3. Bellou V, Andronikidis A, 2008. The impact of internal service quality on customer service behavior: Evidence from the banking sector. International Journal of Quality \& Reliability Management. 25(9): 943-954.

4. Chelladuraie P, 2003. Motivation performance of sport organization staff. Journal of sport management. 18: $73-82$.

5. Di Xie M, 2005. Exploring organizational learning culture, job satisfaction, motivation to learn, organizational commitment and internal service quality in a sport organization. School of the Ohio state university.

6. Elahi AR, Goudarzi M, Khabiri M, 2004. Review the performance of professional league football in Iran in comparison with Japan's professional league football. Harakat Journal. 27: 55-71.

7. Hair, J.F., Ralph, E.A., Ronald, L.I. and William C.B., (2003), Multivariate Data Analysis, 4th Edition, Prentice Hall, New Jersey.

8. Hardeep Chahal and R.D. Sharma (2004), "Managing Health Care Service Quality in a Primary Health Care Centre", MetamorphosisJMR, 3 (2), pp.112-131.

9. Hallowell R, Schlesinger LA, Zornitsky J, 1996. Internal service quality, customer and job satisfaction: Linkages and implications for management. Human Resource Planning. 19(2): 20-31.

10. Hauser J, Simester D, Wernerfelt B, 1996. Internal customers and internal suppliers. Journal of Marketing Resource. 33(3): 268-280.

11. Heskett JL, Jones TO, Loveman GW, Sasser WE, Schlesinge LA, 1994. Putting the Service-Profit
Chain to Work. Harvard Business Review. 72(2): 164-170

12. Khabiri M, 2002. The compare of the performance of internal and external trainers the National football teams of Iran from beginning to the 2000 . Harakat Journal. 17: 45-62.

13. Liang wang G, 2010. A Study of How the Internal-Service Quality of International Tourist Hotels Affects Organizational Performance: Using Employees' Job Satisfaction as the Mediator. University of Science and Technology, Taiwan.

14. Mackay KL, Crompton JL, 1990. Measuring the quality of recreation services. Journal of Park and Recreation Administration. 8(2): 47-56.

15. Meng-Xia C, 2003. A study of correlations among internal-service quality, employee's job satisfaction, organizational commitment and customer-oriented behaviours: Taking Bank A for example, Institute of Commerce Automation and Management, National Taipei University of Technology.

16. Narimani M, Aryapooran S, Abolghasemi A, 2007. Comparative efficacy of two methods to increase efficiency and performance on mental imagery and relaxation sports of taekwondo athletes. Harakat Journal. 32: 5-17.

17. Parasuraman, A., A Valarie Zeithaml and Leonard L.Berry (1988), "SERVQUAL: A Multi. Item Scale for measuring consumer perceptions of service quality", Journal of Retailing, 64 (Spring), pp.12-40.

18. Qin-Nan W, 2009. A study of the relations among internal-service quality, employee satisfaction and job performance: Taking the example of vehicle insurance-handling staff at Taiwanese property insurers. Graduate Institute of Business Administration, National Taipei University, Taiwan.

19. Yue-Xia C, 2009. Examining how the quality of internal services affects customer satisfaction: Taking the example of local tax agencies in Eastern Taiwan, In-service Master's Program, Graduate Institute of Public Administration, National Dong Hwa University, Taiwan.

20. Chahal, Hardeep (2003), "Strategies for enhancing consumer satisfaction in Rural Health Services in 
J \& K”, Indian Journal of Marketing, 33 (9), pp.13-17.

21. Hardeep Chahal and R.D. Sharma (2004), "Managing Health Care Service Quality in a Primary Health Care Centre", MetamorphosisJMR, 3 (2), pp.112-131

22. Sharma, R.d. and Chahal, Hardeep (1996), "A Study of Patients satisfaction in outdoor services of Private Health Care Facilities", Vikalpa, 24, pp.69-76.

23. Sharma, R.D., and Chahal, Hardeep (1995), "Patient satisfaction in Public Health System-A Case Study", The Indian Journal of Social Work, 61 (4), pp.445-456.

24. Sharma, R.D., and Gupta Mahesh (2004), "Patient Satisfaction in Public Out Patient Health Care Services", The Journal of Health Management, 6 (1), pp.23-45.

25. Zeithaml, A. Valarie and J. Mary Bitner (2003), "Working paper No.277", Manchester Business School, Manchester.

26. Zeithaml, A., Valarie, A. Parasuraman and L.L.Berry (1990), Delivery Quality Service: Balancing Customer Perception and Expectations, New York: Free Press. 